\title{
Analisis faktor yang Berhubungan dengan Kejadian Efek Samping pada Akseptor Putus Pakai IUD/Implant di Kabupaten Mamuju Tengah
}

\author{
$\underline{\text { Sukardi }}^{1}$ Ashriady ${ }^{2}$ Fajar Akbar $^{3}$ \\ ${ }^{1}$ Perwakilan BKKBN Provinsi Sulawesi Barat \\ ${ }^{2,3}$ JurusanKebidananPoltekkesKemenkesMamuju \\ Corresponding author: Sukardi \\ Email: sukardisaleh@gmail.com
}

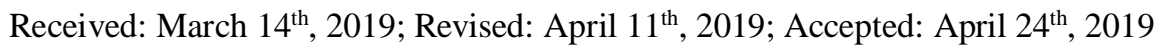

\begin{abstract}
In 1994 the International Conference on Population and Development (ICPD) has changed the paradigm in managing population problems, which was originally oriented to reducing fertility (humans as objects) to prioritizing individual reproductive health by respecting the reproductive rights of each individual (human being as the subject). The problem that occurs is the participation of couples of reproductive age in family planning programs is not yet complete. One problem that needs attention is that there are PUSs who drop out or no longer use contraception. The number of family planning dropouts in Indonesia has increased, from $11.46 \%$ in 2008 to $15.09 \%$ in 2012. The potential number of Indonesian population in 2015 reaches 300 million if the family planning movement or the number of family planning dropouts increases or does not run as expected. The results of the study (Maskanah, 2009) showed that the higher the incompatibility of contraceptive use (experiencing side effects), the higher the incidence of family planning contraception dropouts. This type of research is quantitative research with a cross sectional study design. Time of study in November 2018. The population is participants who dropped out of IUD/Implant KB in Central Mamuju Regency in 2018 with a population of 32. The study sample was taken using the Total Sampling method.The results showed that there was a relationship between maternal education level, quality of family planning services, and husband support with the incidence of side effects in drop-outs using IUD/Implant in Central Mamuju District. Efforts to increase PLKB coaching are needed for Participants in IUD and Implant KB, especially in the first month after installation. Improving the quality of family planning services, especially in signing informed consent and screening prospective acceptors before being served.Increased IEC to husbands about the importance of family planning that family-based affairs are not merely the matter of the wife.
\end{abstract}

Keyword: family planning, drop out; side effects; IUD; implant

\section{Pendahuluan}

Program KB mempunyai arti yang sangat penting dalam upaya mewujudkan manusia Indonesia sejahtera di samping program pendidikan dan kesehatan. Undang-undang No 10 tahun 1992 tentang Perkembangan Kependudukan dan Pembangunan Keluarga Sejahtera yang kemudian di revisi dengan Undang-undang No 52 Tahun 2009 tentang perkembangan Kependudukan dan Pembangunan Keluarga menyebutkan bahwa Keluarga Berencana adalah upaya mengatur kelahiran anak, jarak dan usia ideal melahirkan, mengatur kehamilan, melalui promosi, perlindungan dan bantuan sesuai dengan hak reproduksi untuk mewujudkan keluarga berkualitas (BKKBN, 2012).

Permasalahan yang terjadi adalah keikutsertaan pasangan usia subur dalam program KB belum sepenuhnya. Salah satu masalah yang perlu mendapat perhatian dalam pelaksanaan program KB adalah terdapat PUS yang drop out atau tidak aktif lagi menggunakan kontrasepsi. Sebagaimana dalam teori perilaku Green dijelaskan bahwa perilaku seseorang dipengaruhi oleh faktor predisposisi, faktor pemungkin, dan faktor penguat. Dalam kontek perilaku drop out $\mathrm{KB}$, yang termasuk dalam faktor predisposisi antara lain adalah karakteristik demografi (umur, tingkat pendidikan, pendapatan, dan alasan drop out $\mathrm{KB}$ ), pengetahuan tentang $\mathrm{KB}$ dan sikap 
terhadap KB. Selanjutnya yang termasuk dalam faktor pemungkin antara lain biaya, akses dan ketersediaan alat kontrasepsi dan termasuk dalam faktor penguat antara lain adalah dukungan keluarga, teman, dan tenaga kesehatan (Kurniawati \& Rokayah 2011).

Salah satu indikator penting untuk mengukur kualitas pemakaian alat/cara $\mathrm{KB}$ adalah putus pakai. Secara umum, wanita yang mulai memakai alat/cara kontrasepsi di Provinsi Sulawesi Barat berhenti memakai alat/cara itu dalam 12 bulan setelah mulai memakai. Alasan berhenti memakai mencakup semua metode diantaranya Hamil ketika memakai $(4,4 \%)$, ingin hamil $(26,7 \%)$, suami tidak setuju $(0,9 \%)$, ingin cara yang lebih efektif $(7,5 \%)$, efek samping/ masalah kesehatan $(38,7 \%)$, akses ketersediaan $(1,8 \%)$, biaya mahal $(0,6 \%)$, tidak nyaman $(3,4 \%)$, tidak peduli $(2,1 \%)$, menopause $(1,3 \%)$, jarang kumpul/ suami jauh $(7,5 \%)$ cerai $(2,2 \%)$, IUD lepas sendiri $(0,6 \%)$ lainnya $(2,2 \%)$, tidak terjawab $(0,1)$. Alasan karena efek samping dan ingin hamil menjadi alasan yang banyak diutarakan oleh wanita di Provinsi Sulawesi Barat untuk semua metode begitupun yang terjadi dengan alasan untuk metode Implant. (Sukardi\& Irma, 2018).

Efek samping dalam menggunakan kontrasepsi susuk KB (implan) yaitu sangat umum bila terdapat bercak atau haid ringan, bila haid tak teratur, tidak mendapat haid, yang tidak umum adalah munculnya jerawat atau gatal-gatal, perubahan nafsu makan, berat badan bertambah, rambut rontok atau tumbuh rambut di wajah (Oka 2017). Efek samping IUD antara lain keluar darah dari vagina berupa bercak-bercak perdarahan (spoting), kadang-kadang ditemukan keputihan yang bertambah banyak, disamping itu pada saat berhubungan terjadi pergeseran IUD dari posisi, baik sebagian maupun keseluruhan (Maskanah 2009).

Secara substantif, pasangan usia subur diharapkan menggunakan MKJP setelah persalinan untuk menghindari resiko empat terlalu terutama untuk menjaga jarak kehamilan atau kelahiran berikutnya yang aman dan sehat, selain itu juga untuk menurunkan resiko terlalu banyak anak (Kementerian Kesehatan Republik Indonesia 2013). Berdasarkan data Riskesdas tahun 2013 ditunjukkan bahwa penggunaan metode kontrasepsi jangka panjang $(10,2 \%)$ di Indonesia lebih sedikit dibandingkan dengan Non MKJP $(49,1) \quad$ (Kementerian Kesehatan Republik Indonesia 2013). Target kepesertaan KB aktif
MKJP secara nasional pada tahun 2015 adalah 20,5\% (Oka 2017).

Berdasarkan studi pendahuluan yang dilakukan (Aini et al. 2016) diperoleh bahwa salah satu alasan akseptor berhenti menggunakan kontrasepsi yaitu karena efek samping yang timbul setelah menggunakan kontrasepsi. Hasil penelitian yang dilakukan oleh (Herlinawati 2004) menunjukkan bahwa faktor program yaitu kualitas pelayanan kontrasepsi meliputi pemberian informasi berpengaruh terhadap kejadian drop out alat kontrasepsi KB. Hasil penelitian (Maskanah 2009) yang menunjukkan bahwa semakin tinggi ketidakcocokan penggunaan alat kontrasepsi (mengalami efek samping) maka akan semakin tinggi kejadian drop out alat kontrasepsi KB.

Berdasarkan uraian di atas, peneliti tertarik untuk meneliti analisis faktor yang berhubungan dengan kejadian efek samping pada akseptor putus pakai kontrasepsi IUD/Implant di Kabupaten Mamuju Tengah. Tujuan penelitian untuk menganalisis faktor yang berhubungan dengan kejadian efek samping pada akseptor putus pakai IUD/ Implant di Kabupaten Mamuju Tengah.

\section{Metode Penelitian}

Jenis penelitian yang digunakan adalah penelitian kuantitatif dengan desain cross sectional study. Penelitian ini berlokasi di Kabupaten Mamuju Tengah. Waktu penelitian akan dilaksanakan selama 3 bulan yaitu bulan Oktober Desember 2018.

Populasi dalam penelitian ini adalah peserta drop out KB IUD/Implant yang ada di Kabupaten Mamuju Tengah tahun 2018 dengan jumlah populasi sebanyak 32. Sampel penelitian diambil dengan menggunakan metode Total Sampling. Penelitian ini telah mendapat persetujuan dariKepalaPerwakilan BKKBN Provinsi Sulawesi Barat sesuai surat penyataan ethical clearance publikasi ilmiah No.:281/LB.01/J10/2019 tertanggal 14 Maret 2019

Analisis univariat disesuaikan dengan jenis data yang ada, berbeda pada data numerik dan kategorik. Untuk data numerik, analisis univariat mengunakan nilai mean (rata-rata), median, inter quartile range, minimal dan maksimal. Tergantung dengan kondisi nilai ekstrim dan distribusi normal, sedangkan data kategorik, analisis univariat hanya menampilkan distribusi frekuensi dengan ukuran presentase atau proporsi.Analisis bivariat merupakan analisis yang bertujuan untuk melihat hubungan antara satu variabel independen dengan 
variabel dependennya.Analisis multivariat yang ingin dilakukan adalah regresi logistik. Dalam penelitian ini variabel independen adalah karakteristik akseptor, efek samping, pembinaan PLKB, kualitas pelayanan KB, dukungan suami serta rumor IUD dan variabel dependennya adalah kejadian putus pakai alat kontrasepsi IUD/Implant.

\section{Hasil dan Pembahasan}

Dari hasil pengumpulan data yang telah dilaksanakan di Kabupaten Mamuju Tengah dengan jumlah responden 32 orang, maka hasil penelitian akan diuraikan berdasarkan karakteristik responden yang terdiri dari umur, tingkat pendidikan, status pekerjaan, dan paritas. Kemudian dilanjutkan dengan penyajian variabel penelitian yang meliputi efek samping, pembinaan PLKB, kualitas pelayanan KB, dukungan suami, rumor IUD/Implant dan putus pakai IUD/Implant sebagai berikut:

\section{Karakteristik Responden dengan Kejadian Efek Samping pada Akseptor Putus Pakai IUD/Implant Umur Ibu \\ Tabel 1 \\ Hubungan Karakteristik Responden berdasarkan Umur Ibu dengan Kejadian Efek Samping pada}

Akseptor Putus Pakai IUD/Implantdi Kabupaten Mamuju Tengah

\begin{tabular}{|c|c|c|c|c|c|c|}
\hline \multirow{4}{*}{ Umur Ibu } & \multicolumn{3}{|c|}{$\begin{array}{c}\text { Kejadian Efek Samping pada Akseptor } \\
\text { Putus Pakai IUD/Implant }\end{array}$} & \multirow{3}{*}{ Total } & & \multirow{4}{*}{$\mathrm{P}$} \\
\hline & \multirow[b]{2}{*}{ Efek Samping } & \multirow[t]{2}{*}{ Bukan } & \multirow{2}{*}{$\begin{array}{l}\text { Efek } \\
\text { Sampin } \\
\text { g }\end{array}$} & & & \\
\hline & & & & & & \\
\hline & $\%$ & $\mathrm{n}$ & $\%$ & $\mathrm{n}$ & $\%$ & \\
\hline$\leq 20$ tahun & 100 & 0 & 0 & 2 & 100 & \\
\hline $21-35$ tahun & 46,7 & 8 & 53,3 & 15 & 100 & 0,279 \\
\hline$>35$ tahun & 40,0 & 9 & 60,0 & 15 & 100 & \\
\hline
\end{tabular}

Tabel 1 menunjukkan hasil penelitian bahwa mayoritas responden berumur $>35$ tahun dengan Responden yang berumur $\leq 20$ tahun dengan efek bukan efek samping yaitu sebanyak 9 orang $(60 \%)$. samping sebanyak 2 orang $(100 \%)$.

\section{Tingkat Pendidikan Ibu}

\section{Tabel 2}

Hubungan Karakteristik Responden berdasarkan Tingkat Pendidikan Ibu denganKejadian Efek Samping pada Akseptor Putus Pakai IUD/Implant di Kabupaten Mamuju Tengah

\begin{tabular}{|c|c|c|c|c|c|c|c|}
\hline \multirow{3}{*}{$\begin{array}{l}\text { Tingkat Pendidikan } \\
\text { Ibu }\end{array}$} & \multicolumn{4}{|c|}{$\begin{array}{c}\text { Kejadian Efek Samping pada Akseptor } \\
\text { Putus Pakai IUD/Implant }\end{array}$} & \multirow{2}{*}{\multicolumn{2}{|c|}{ Total }} & \multirow{3}{*}{$\mathrm{p}$} \\
\hline & \multicolumn{2}{|c|}{ Efek Samping } & \multicolumn{2}{|c|}{$\begin{array}{l}\text { Bukan Efek } \\
\text { Samping }\end{array}$} & & & \\
\hline & $\mathrm{N}$ & $\%$ & $\mathrm{n}$ & $\%$ & $\mathrm{n}$ & $\%$ & \\
\hline Tidak Tamat SD & 1 & 33,3 & 2 & 66,7 & 3 & 100 & \multirow{5}{*}{0,013} \\
\hline Tamat SD & 1 & 9,2 & 10 & 90,8 & 11 & 100 & \\
\hline Tamat SMP & 7 & 87,5 & 1 & 12,5 & 8 & 100 & \\
\hline Tamat SMA & 4 & 57,1 & 3 & 42,9 & 7 & 100 & \\
\hline Tamat PT & 2 & 66,7 & 1 & 33,3 & 3 & 100 & \\
\hline
\end{tabular}

Tabel 2 menunjukkan hasil penelitian bahwa mayoritas responden memiliki tingkat pendidikan tamat SD dengan bukan efek samping yaitu sebanyak 10 orang $(90,8 \%)$. Responden yang memiliki tingkat pendidikan tamat SMP dengan efek samping sebanyak 7 orang $(87,5 \%)$.

Berdasarkan hasil analisis statistik dengan chi-square diperoleh nilai $\mathrm{p}=0,013 \quad(\mathrm{p}<\alpha=0,05)$. Hal ini berarti bahwa ada hubungan antara tingkat Copyright @ 2019 Authors, JURNAL KEBIDANAN, e-ISSN 2621-2870, p-ISSN 2089-7669 
pendidikan ibu dengan kejadian efek samping pada

akseptor putus pakai IUD/Implant di Kabupaten

Mamuju Tengah.

\section{Status Pekerjaan Ibu}

Tabel 3

Hubungan Karakteristik Responden berdasarkan Status Pekerjaan Ibu denganKejadian Efek Samping pada Akseptor Putus Pakai IUD/Implant

\begin{tabular}{|c|c|c|c|c|c|c|c|}
\hline \multirow{3}{*}{$\begin{array}{l}\text { Status Pekerjaan } \\
\text { Ibu }\end{array}$} & \multicolumn{4}{|c|}{$\begin{array}{c}\text { Kejadian Efek Samping pada Akseptor } \\
\text { Putus Pakai IUD/Implant }\end{array}$} & \multirow{2}{*}{\multicolumn{2}{|c|}{ Total }} & \multirow{3}{*}{$\mathrm{p}$} \\
\hline & \multicolumn{2}{|c|}{ Efek Samping } & \multicolumn{2}{|c|}{$\begin{array}{l}\text { Bukan Efek } \\
\text { Samping }\end{array}$} & & & \\
\hline & $\mathrm{N}$ & $\%$ & $\mathrm{n}$ & $\%$ & $\mathrm{n}$ & $\%$ & \\
\hline Tidak Bekerja & 10 & 40,0 & 15 & 60,0 & 25 & 100 & 0296 \\
\hline Bekerja & 5 & 71,4 & 2 & 28,6 & 7 & 100 & \\
\hline
\end{tabular}

Tabel 3 menunjukkan hasil penelitian bahwa mayoritas responden berstatus tidak bekerja dengan bukan efek samping yaitu sebanyak 15 orang $(60 \%)$. Responden yang berstatus tidak bekerja dengan efek samping sebanyak 10 orang $(40 \%)$.

Berdasarkan hasil analisis statistik dengan chi-square diperoleh nilai $\mathrm{p}=0,296(\mathrm{p}>\alpha=0,05)$. Hal ini berarti bahwa tidak ada hubungan antara status pekerjaan ibu dengan kejadian efek samping pada akseptor putus pakai IUD/Implant di Kabupaten Mamuju Tengah.

\section{Paritas}

Tabel 4

Hubungan Karakteristik Responden berdasarkan Paritas denganKejadian Efek Samping pada Akseptor Putus Pakai IUD/Implant

\begin{tabular}{|c|c|c|c|c|c|c|c|}
\hline \multirow{3}{*}{ Paritas } & \multicolumn{4}{|c|}{$\begin{array}{c}\text { Kejadian Efek Samping pada Akseptor } \\
\text { Putus Pakai IUD/Implant }\end{array}$} & \multirow{2}{*}{\multicolumn{2}{|c|}{ Total }} & \multirow{3}{*}{$\mathrm{p}$} \\
\hline & \multicolumn{2}{|c|}{ Efek Samping } & \multicolumn{2}{|c|}{$\begin{array}{l}\text { Bukan Efek } \\
\text { Samping }\end{array}$} & & & \\
\hline & $\mathrm{n}$ & $\%$ & $\mathrm{n}$ & $\%$ & $\mathrm{n}$ & $\%$ & \\
\hline$\leq 2$ anak & 8 & 53,3 & 7 & 46,7 & 15 & 100 & \\
\hline$>2$ anak & 7 & 41,2 & 10 & 58,8 & 17 & 100 & 0,739 \\
\hline
\end{tabular}

Tabel 4menunjukkan hasil penelitian bahwa mayoritas responden memiliki paritas >2 anak dengan bukan efek samping yaitu sebanyak 10 orang $(58,8 \%)$. Responden yang memiliki paritas $\leq$ 2 anak dengan efek samping sebanyak 8 orang $(53,3 \%)$.
Berdasarkan hasil analisis statistik dengan chi-square diperoleh nilai $\mathrm{p}=0,739 \quad(\mathrm{p}>\alpha=0,05)$. Hal ini berarti bahwa tidak ada hubungan antara paritas dengan kejadian efek samping pada akseptor putus pakai IUD/Implant di Kabupaten Mamuju Tengah.

\section{Pembinaan PLKB}

Tabel 5

Hubungan Pembinaan PLKB denganKejadian Efek Samping pada Akseptor Putus Pakai IUD/Implant Kejadian Efek Samping pada Akseptor

\begin{tabular}{|c|c|c|c|c|c|c|c|}
\hline \multirow{3}{*}{ Pembinaan PLKB } & \multicolumn{4}{|c|}{ Putus Pakai IUD/Implant } & \multirow{2}{*}{\multicolumn{2}{|c|}{ Total }} & \multirow{3}{*}{$\mathrm{p}$} \\
\hline & \multicolumn{2}{|c|}{ Efek Samping } & \multicolumn{2}{|c|}{$\begin{array}{c}\text { Bukan Efek } \\
\text { Samping }\end{array}$} & & & \\
\hline & $\mathrm{n}$ & $\%$ & $\mathrm{n}$ & $\%$ & $\mathrm{n}$ & $\%$ & \\
\hline Kurang & 10 & 45,5 & 12 & 54,5 & 22 & 100 & \multirow{2}{*}{1,000} \\
\hline Cukup & 5 & 500 & 5 & 500 & 10 & 1 & \\
\hline
\end{tabular}


Tabel 5 menunjukkan hasil penelitian bahwa mayoritas responden menjawab pembinaan PLKB dalam kategori kurang dengan bukan efek samping yaitu sebanyak 12 orang (54,5\%). Responden yang menjawab pembinaan PLKB dalam kategori kurang dengan efek samping sebanyak 10 orang $(45,5 \%)$.
Berdasarkan hasil analisis statistik dengan chi-square diperoleh nilai $p=1,000(p>\alpha=0,05)$. Hal ini berarti bahwa tidak ada hubungan antara pembinaan PLKB dengan kejadian efek samping pada akseptor putus pakai IUD/Implant di Kabupaten Mamuju Tengah.

\section{Kualitas Pelayanan KB}

Tabel 6

Hubungan Kualitas Pelayanan KB denganKejadian Efek Samping pada Akseptor Putus Pakai IUD/Implant

\begin{tabular}{|c|c|c|c|c|c|c|c|}
\hline \multirow{3}{*}{$\begin{array}{l}\text { Kualitas Pelayanan } \\
\text { KB }\end{array}$} & \multicolumn{4}{|c|}{$\begin{array}{c}\text { Kejadian Efek Samping pada Akseptor } \\
\text { Putus Pakai IUD/Implant }\end{array}$} & \multirow{2}{*}{\multicolumn{2}{|c|}{ Total }} & \multirow{3}{*}{$\mathrm{p}$} \\
\hline & \multicolumn{2}{|c|}{ Efek Samping } & \multicolumn{2}{|c|}{$\begin{array}{l}\text { Bukan Efek } \\
\text { Samping }\end{array}$} & & & \\
\hline & $\mathrm{n}$ & $\%$ & $\mathrm{~N}$ & $\%$ & $\mathrm{n}$ & $\%$ & \\
\hline Kurang Berkualitas & 4 & 23,5 & 13 & 76,5 & 17 & 100 & \\
\hline Cukup Berkualitas & 11 & 73,3 & 4 & 26,7 & 15 & 100 & 0,014 \\
\hline
\end{tabular}

Tabel 6 menunjukkan hasil penelitian bahwa mayoritas responden menjawab kualitas pelayanan KB dalam kategori kurang berkualitas dengan bukan efek samping yaitu sebanyak 13 orang $(76,5 \%)$. Responden yang menjawab kualitas pelayanan KB dalam kategori cukup berkualitas dengan efek samping sebanyak 11 orang $(73,3 \%)$.
Berdasarkan hasil analisis statistik dengan chi-square diperoleh nilai $\mathrm{p}=0,014 \quad(\mathrm{p}<\alpha=0,05)$. Hal ini berarti bahwa ada hubungan antara kualitas pelayanan KB dengan kejadian efek samping pada akseptor putus pakai IUD/Implant di Kabupaten Mamuju Tengah.

\section{Dukungan Suami}

Tabel 7

Hubungan Dukungan Suami denganKejadian Efek Samping pada Akseptor Putus Pakai IUD/Implant

\begin{tabular}{|c|c|c|c|c|c|c|c|}
\hline \multirow{3}{*}{ Dukungan Suami } & \multicolumn{4}{|c|}{$\begin{array}{c}\text { Kejadian Efek Samping pada } \\
\text { Akseptor Putus Pakai IUD/Implant }\end{array}$} & \multirow{2}{*}{\multicolumn{2}{|c|}{ Total }} & \multirow{3}{*}{$\mathrm{p}$} \\
\hline & \multicolumn{2}{|c|}{ Efek Samping } & \multicolumn{2}{|c|}{$\begin{array}{l}\text { Bukan Efek } \\
\text { Samping }\end{array}$} & & & \\
\hline & $\mathrm{N}$ & $\%$ & $\mathrm{n}$ & $\%$ & $\mathrm{n}$ & $\%$ & \\
\hline Kurang Mendukung & 7 & 31,8 & 15 & 68,2 & 22 & 100 & 0020 \\
\hline Mendukung & 8 & 80,0 & 2 & 20,0 & 10 & 100 & 0,032 \\
\hline
\end{tabular}

Tabel 7 menunjukkan hasil penelitian bahwa mayoritas responden menjawab dukungan suami dalam kategori kurang mendukung dengan bukan efek samping yaitu sebanyak 15 orang $(68,2 \%)$. Responden yang menjawab dukungan suami dalam kategori mendukung dengan efek samping sebanyak 8 orang $(80 \%)$.

Berdasarkan hasil analisis statistik dengan chi-square diperoleh nilai $p=0,032(p<\alpha=0,05)$. Hal ini berarti bahwa ada hubungan antara dukungan suami dengan kejadian efek samping pada akseptor putus pakai IUD/Implant di Kabupaten Mamuju Tengah.

\section{Karakteristik Responden dengan Kejadian Efek Samping pada Akseptor Putus Pakai IUD/Implant}

\section{Umur Ibu}

Usia wanita yang muda lebih besar keinginan untuk memiliki anak daripada usia wanita yang berumur tua. Sebagian besar lebih memilih menggunakan Non-MKJP dari pada MKJP karena lebih cepat untuk mengembalikan kesuburan. Apabila sewaktu-waktu ingin merencanakan menambah anak tidak perlu repot untuk pergi ke 
tempat pelayanan kesehatan untuk melepas alat kontrasepsi. Kategori usia berisiko yaitu terletak pada umur $<20$ tahun dan $>35$ tahun. Usia $<20$ tahun memiliki risiko besar untuk menggunakan alat kontrasepsi di mana organ reproduksi belum berfungsi sempurna. Sedangkan usia $>35$ tahun merupakan rawan untuk memiliki anak lagi, alat reproduksi sudah tidak sekuat usia 20 - 30 tahun, sehingga diharapkan untuk mengakhiri kehamilannya dengan menggunakan MKJP (Sumartini \& Indriani, 2016).

Hasil penelitian ini sejalan dengan penelitian (Sumartini \& Indriani, 2016), dimana pada penelitian ini sebagian besar responden yang mengalami putus pakai IUD/Implant adalah kategori 21 - 35 tahun dan $>35$ tahun. Sebagian besar responden yang mengalami putus pakai tersebut bukan karena efek samping. Menurut peneliti hal itu diakibatkan karena alasan masalah kesehatan atau karena alasan merasa tidak subur/anak sudah besar.

Secara statistik, hasil penelitian ini menunjukkan bahwa tidak ada hubungan antara umur ibu dengan kejadian efek samping pada akseptor putus pakai IUD/Implant di Kabupaten Mamuju Tengah. Menurut Hasil penelitian (Sumarmini, 2010) mengenai karakteristik responden berdasarkan umur menunjukkan bahwa mayoritas responden termasuk dalam kelompok umur 20 - 35 tahun. Menurut Notoatmodjo (2003), Umur merupakan priode penyesuaian terhadap pola- pola kehidupan baru. Pada masa dewasa ini ditandai dengan adanya perubahan-perubahan jasmani dan mental. Semakin bertambah umur seseorang maka akan semakin bertambah keinginan dan pengetahuannya tentang kesehatan.

\section{Tingkat Pendidikan Ibu}

Penelitian ini menunjukkan bahwa sebagian besar responden yang mengalami putus pakai IUD/ Implant memiliki tingkat pendidikan Tamat SD. Sejalan dengan penelitian (Permatasari, Wati, \& Ramani, 2013) yang menunjukkan bahwa semakin tinggi tingkat pendidikan akseptor IUD maka kemungkinan untuk berhenti menggunakan metode tersebut semakin kecil.

Hasil penelitian ini juga menunjukkan bahwa sebagian besar responden putus pakai IUD/Implant yang mengalami efek samping memiliki tingkat pendidikan tamat SMP. Tingkat pendidikan tersebut merupakan tingkat pendidikan dasar, dimana seseorang dapat memiliki keterampilan untuk melakukan analisis dalam pemecahan masalah jika berada pada tingkat pendidikan menengah.

Secara statistik, hasil penelitian ini menunjukkan bahwa ada hubungan antara tingkat pendidikan ibu dengan kejadian efek samping pada akseptor putus pakai IUD/Implant di Kabupaten Mamuju Tengah. Sejalan dengan penelitian (Permatasari et al., 2013) yang menunjukkan bahwa hasil analisis multivariabel menggunakan uji Chi-square, terdapat tiga variabel yang berhubungan secara signifikan dengan penghentian penggunaan IUD, yaitu usia, jumlah anak, dan pendidikan akseptor IUD. Hal ini didasarkan pada nilai $\mathrm{p}$ dari ketiga variabel tersebut yang kurang dari $\alpha=0,05$.

\section{Status Pekerjaan Ibu}

Hasil penelitian ini menunjukkan bahwa sebagian besar responden putus pakai IUD/Implant berstatus tidak bekerja. Sejalan dengan penelitian (Aini et al., 2016) yang menunjukkan bahwa responden yang tidak memiliki pekerjaan lebih banyak yang memilih drop out $(80,8 \%)$, sedangkan responden yang memiliki pekerjaan hanya sedikit yang memilih tidak drop out $(23,1 \%)$.

Hal ini berbeda dengan hasil penelitian (Hardianti, Salmah, \& Sarake, 2013) yang menunjukkan bahwa pekerjaan merupakan faktor penting terhadap drop out KB. Dari hasil penelitian tersebut memperlihatkan bahwa peserta yang bekerja sebagai petani lebih berpotensi untuk drop out ber-KB.

Secara statistik, hasil penelitian ini menunjukkan bahwa tidak ada hubungan antara status pekerjaan ibu dengan kejadian efek samping pada akseptor putus pakai IUD/Implant di Kabupaten Mamuju Tengah.

\section{Paritas}

Hasil penelitian ini menunjukkan bahwa sebagian besar responden putus pakai IUD/Implant memiliki paritas $>2$ anak. Hasil penelitian ini berbeda dengan penelitian Permatasari et al., 2013 dimana didapatkan hubungan yang signifikan antara jumlah anak dengan penghentian penggunaan IUD. Hasil analisis bivariabel menunjukkan bahwa akseptor IUD yang memiliki jumlah anak <2 memiliki risiko 1,874 kali lebih besar untuk berhenti menggunakan metode tersebut daripada akseptor IUD yang memiliki jumlah anak $\geq 2$. Hasil penelitian ini searah dengan penelitian yang dilakukan oleh Maryatun, yang menyatakan bahwa terdapat hubungan antara paritas dengan pemakaian metode kontrasepsi. 
Hasil bivariat antara kedua variabel ini menunjukan kecenderungan bahwa sebagian responden yang memakai metode kontrasepsi IUD mempunyai paritas lebih dari 2. Penelitian serupa yang dilakukan oleh Rosyatuti menyebutkan bahwa terdapat hubungan paritas dengan pemakaian metode kontrasepsi IUD baik secara langsung maupun tidak langsung. Dijelaskan semakin tinggi anak yang pernah dilahirkan maka akan memberikan peluang lebih banyak keinginan ibu untuk membatasi kelahiran.

Hasil penelitian menunjukkan bahwa sebagian besar responden putus pakai IUD/Implant memiliki paritas >2 anak dengan bukan efek samping. Menurut peneliti, responden yang putus pakai IUD/Implant tersebut bukan disebabkan karena adanya efek samping tetapi karena faktor lain seperti alasan masalah kesehatan atau karena alasan merasa tidak subur/anak sudah besar. Hal ini diperkuat dengan penelitian (Juniastuti, 2017), berdasarkan wawancara peneliti pada beberapa responden, alasan menggunakan IUD karena para responden belum mau melahirkan dalam 2 hingga 3 tahun lagi sehingga menggunakan alat kontrasepsi jangka panjang, selain itu akseptor telah mengerti tentang kurangnya efek samping bila menggunakan IUD dibandingkan menggunakan suntik dan pil KB.

Secara statistik, hasil penelitian ini menunjukkan bahwa tidak ada hubungan antara paritas dengan kejadian efek samping pada akseptor putus pakai IUD/Implant di Kabupaten Mamuju Tengah.

\section{Pembinaan PLKB}

Berdasarkan hasil penelitian bahwa mayoritas responden menjawab pembinaan PLKB dalam kategori kurang dengan bukan efek samping yaitu sebanyak 12 orang $(54,5 \%)$. Responden yang menjawab pembinaan PLKB dalam kategori kurang dengan efek samping sebanyak 10 orang $(45,5 \%)$. Pemberian informasi dan konseling yang berkelanjutan dan efektif kepada akseptor KB akan memperkecil risiko penggantian alat kontrasepsi serta menjamin loyalitas dan keberlangsungan penggunaan (Rahardja, 2011).

\section{Kualitas Pelayanan KB}

Mayoritas responden menjawab kualitas pelayanan $\mathrm{KB}$ dalam kategori kurang berkualitas dengan bukan efek samping yaitu sebanyak 13 orang $(76,5 \%)$. Adapun responden yang menjawab kualitas pelayanan $\mathrm{KB}$ dalam kategori cukup berkualitas dengan efek samping sebanyak 11 orang $(73,3 \%)$. Kualitas pelayanan mencakup enam aspek, yaitu ketersediaan metode kontrasepsi, kualitas informasi yang diberikan kepada klien (akseptor), hubungan interpersonal antara pemberi layanan dan akseptor, kemampuan teknis petugas pelayanan, mekanisme pelayanan lanjutan, dan ketepatan pemberian layanan (B. Budiman \& Kasto, 2016).

Pelayanan KB yang berkualitas berdampak pada kepuasan pada klien yang dilayani dan terpenuhinya aturan penyelenggaraan Pelayanan KB sesuai dengan kode etik dan standar pelayanan yang telah ditetapkan. Kompetensi tenaga yang memberikan pelayanan KB merupakan faktor yang sangat mempengaruhi kualitas pelayanan KB selain faktor-faktor lain seperti prasarana dan sarana penunjang, alat, dan obat kontrasepsi, ketersediaan pedoman pelayanan dan upaya untuk menjaga mutu. Ditinjau dari sudut standar pelayanan, pelayanan KB yang berkualitas adalah bila tingkat komplikasi, ketidak berlangsungan dan kegagalan rendah atau berada dalam batas toleransi (BKKBN, BPS, \& Kemenkes, 2013).

\section{Dukungan Suami}

Penggunaan alat kontrasepsi merupakan tanggung jawab bersama antara pria dan wanita sebagai pasangan, sehingga metode kontrasepsi yang dipilih mencerminkan kebutuhan serta keinginan bersama. Dalam hal ini bisa saja pria yang memakai kontrasepsi seperti kondom, coitus interuptus dan vasektomi, suami mempunyai tanggung jawab utama. Berdasarakan hasil penelitian bahwa mayoritas responden menjawab dukungan suami dalam kategori kurang mendukung dengan bukan efek samping yaitu sebanyak 15 orang $(68,2 \%)$. Dalam hal ini menunjukkan kurangnya dukungan suami pada akseptor putus pakai IUD/Implan. Responden yang menjawab dukungan suami dalam kategori mendukung dengan efek samping sebanyak 8 orang $(80 \%)$.

\section{Simpulan}

Sebagian besar responden yang mengalami putus pakai IUD/Implant adalah kategori $21-35$ tahun dan $>35$ tahun, tingkat pendidikan tamat SMP, berstatus tidak bekerja, paritas $>2$ anak .Sebagian besar responden yang menjawab pembinaan PLKB dalam kategori kurang, tidak mengalami efek samping. Sebagian besar responden yang menjawab kualitas pelayanan $\mathrm{KB}$ dalam kategori kurang berkualitas, tidak 
mengalami efek samping.Sebagian besar responden yang menjawab dukungan suami dalam kategori kurang mendukung, tidak mengalami efek samping.

Sasaran pelayanan KB dengan kriteria pasangan usia subur varietas rendah perlu diperhatikan, mengintensifkan KIE KB kepada PUS yang berpendidikan rendah dan tidak bekerja tentang efek samping Alat atau Obat Kontrasepsi yang digunakan karena mereka ini mempunyai keterbatasan informasi dalam mengakses informasi tentang $\mathrm{KB}$, meningkatkan pembinaan PLKB kepada Peserta KB IUD dan Implant terutama pada satu bulan pertama setelah pemasangan, meningkatkan kualitas elayanan KB terutama pada penandatanganan Inform consent dan skrining calon akseptor sebelum dilayani, meningkatkan KIE kepada suami-suami tentang arti penting Keluarga Berencana bahwa urusan berKB tidak hanya semata urusan istri.

\section{Daftar Pustaka}

Aini, A. N., Mawarni, A., \& Dharminto. (2016). Faktor-Faktor Yang Berhubungan Dengan Kejadian Drop Out Akseptor KB di KEcamatan Tembalang Kota Semarang. FKM UNDIP JKM E-Journal, 4, 4. Retrieved from https://ejournal3.undip.ac.id/index.php/jkm/ article/view/13985/13521

BKKBN, BPS, \& Kemenkes. (2013). Survei Demografi dan Kesehatan Indonesia.

BKKBN Provinsi Jawa Tengah. (2012). Umpan Balik Hasil Pelaksanaan Program Keluarga Berencana Nasional Propinsi Jawa Tengah. Semarang.

Budiman, B., \& Kasto, K. (2016). Kualitas Pelayanan Keluarga Berencana di Kecamatan Unaaha Kabupaten Konawe, 23(2), 154-175.

Hardianti, S., Salmah, A. U., \& Sarake, M. (2013). Karakteristik Peserta KB Drop Out Kecamatan Wawotobi Kabupaten Konawe Provinsi Sulawesi Tenggara. Universitas Hasanuddin Makassar. Retrieved from epository.unhas.ac.id/bitstream/handle/1234 56789/9514/SRI

HARDIANTI K11106692.pdf?sequence $=1$

Herlinawati. (2004). Pengaruh Komunikasi, Informasi, Edukasi dan Kualitas Pelayanan Kontrasepsi terhadap Drop Out
Penggunaan Alat Kontrasepsi. Universitas Diponegoro.

Juniastuti, Y. (2017). Hubungan Pengetahuan Akseptor IUD dengan Kecemasan Efek Samping Kontrasepsi IUD di RS Dewi Sartika Kota Kendari Tahun 2017. Kementerian Kesehatan Republik Indonesia Politeknik Kesehatan Kendari.

Kementerian Kesehatan Republik Indonesia. (2013). Situasi Keluarga Berencana di Indonesia. Jakarta.

Kurniawati, R., \& Rokayah, Y. (2011). Analisis faktor-faktor yang berpengaruh terhadap perilaku drop out KB di Desa Caringin Kabupaten Pandeglang Banten. Jurnal Kesehatan, 6(1), 1-9.

Maskanah. (2009). Faktor-Faktor yang Berhubungan dengan Kejadian Drop Out Alat Kontrasepsi Suntik di Desa Mororejo Kecamatan Kaliwungu Kabupaten Kendal. IKM : Universitas Negeri Semarang.

Notoatmodjo, S. (2007). Promosi Kesehatan dan Ilmu Perilaku. Jakarta: Rineka Cipta.

Oka, L. H. C. (2017). Kualitas konseling KB implan yang diberikan oleh bidan kepada akseptor KB baru di Kota Denpasar. Universitas Udayana.

Permatasari, N. E., Wati, D. M., \& Ramani, A. (2013). Determinan Penghentian Penggunaan IUD di Indonesia (Determinants of IUD Discontinuation in Indonesia). Jurnal Pustaka Kesehatan, 1(1), 1-6. Retrieved from download.garuda.ristekdikti.go.id/article.php ?...Determinan Pe...

Rahardja, M. B. (2011). Kualitas Pelayanan Keluarga Berencana dan Penggantian Kontrasepsi di Indonesia. Kesmas: National Public Health Journal, 6(3), 140. https://doi.org/10.21109/kesmas.v6i3.105

Sumarmini, N. I. (2010). Tingkat Pengetahuan Ibu tentang Efek Samping KB Suntik DMPA di BPS Muryati Kalas

Sukardi, \& Irma M. (2018) Laporan Survei Demografi dan Kesehatan Indonesia 2017 Provinsi Sulawesi Barat, Jakarta. Puslitbang BKKBN.

Sumartini, \& Indriani, D. (2016). Pengaruh Keinginan Pasangan Usia Subur (Pus) dalam Penggunaan Metode Kontrasepsi Jangka Panjang. Jurnal Biometrika Dan Kependudukan, $\quad 5(1), \quad$ 27-34. 